\title{
KESADARAN LINGKUNGAN MASYARAKAT DALAM PEMELIHARAAN TAMAN LINGKUNGAN DI JAKARTA PUSAT
}

\author{
Achmad Afandi, Amos Neolaka, Rosmawita Saleh
}

\begin{abstract}
Abstrak
Penelitian ini bertujuan untuk mengetahui sampai sejauh mana tingkat kesadaran lingkungan masyarakat di Jakarta Pusat dalam pemeliharaan taman lingkungan. Tempat penelitian dilakukan di Kelurahan Galur pada taman lingkungan RT 012/RW 04 dan taman lingkungan RT 03/RW 07. Waktu pelaksanaan penelitian dilakukan pada bulan November 2010 s.d Maret 2011

Metode penelitian yang digunakan adalah deskriptif survei. Sampel sebanyak 50 orang responden $(50 \mathrm{KK})$ yang terdiri dari 25 orang responden dari RT 012/RW 04 dan 25 orang responden dari $R T$ 03/RW 07. Instrumen uji coba 20 butir pernyataan diperoleh 16 butir pernyataan yang valid dan reliabel.

Hasil penelitian ini diperoleh Kesadaran lingkungan masyarakat di Jakarta Pusat dalam pemeliharaan taman lingkungan. pada RT 012/04, menunjukkan tingkat pengetahuan yang sangat baik dengan persentase $88,67 \%$ atau kesadaran lingkungan sangat baik Pada sikap/perilaku dengan persentase 74,55 \% ini menunjukkan kesadaran lingkungan baik, sedangkan pada gaya hidup menunjukkan persentase $82,33 \%$ yang berarti kesadaran lingkungan sangat baik.

Sedangkan pada RT 03/07, menunjukkan tingkat pengetahuan yang sangat baik dengan persentase $80,67 \%$ atau kesadaran lingkungan sangat baik. Pada sikap/perilaku dengan persentase 68,33 $\%$ ini menunjukkan kesadaran lingkungan cukup, sedangkan pada gaya hidup menunjukkan persentase $55 \%$ yang berarti kesadaran lingkungan kurang.

Kesimpulan dari penelitian ini adalah nilai indikator pengetahuan, sikap/perilaku dan gaya hidup dalam pemeliharaan taman lingkungan di pada RT 012/04 adalah baik. pada RT 03/07 untuk indikator pengetahuan adalah baik, Sedangkan sikap/perilaku dan gaya hidup tidak mencerminkan kesadaran lingkungan sesungguhnya.
\end{abstract}

Kata kunci : taman lingkungan

\begin{tabular}{|l|c|r|}
\hline $\begin{array}{l}\text { Achmad Afandi } \\
\text { Alumni Jurusan Teknik Sipil }\end{array}$ & $\begin{array}{r}\text { Prof. Dr. Amos Neolaka } \\
\text { Fakultas Teknik } \\
\text { Universitas Negeri Jakarta, 13220 }\end{array}$ & $\begin{array}{r}\text { Dra. Rosmawita Saleh, M.Pd } \\
\text { Staff Pengajar Jurusan Teknik Sipil } \\
\text { Fakultas Teknik }\end{array}$ \\
$\begin{array}{r}\text { Sniversitas Negeri Jakarta, 13220 Pengajar Jurusan Teknik Sipil } \\
\text { Fakultas Teknik }\end{array}$ & $\begin{array}{r}\text { Universitas Negeri Jakarta, 13220 } \\
\text { email : rosmawitasaleh@yahoo.com }\end{array}$ \\
\hline
\end{tabular}




\section{PENDAHULUAN}

Wilayah Jakarta Pusat merupakan salah satu lingkungan hidup yang perlu di tata pola penyebaran tamannya. Penataan taman di Jakarta Pusat tidak asal jadi, tetapi di dalam penyebaran taman mempunyai fungsi dan tujuan yang jelas. Hal ini dimaksudkan untuk mengetahui lokasi, luas taman, kelengkapan sarana dan prasarana taman sesuai dengan kebutuhan standar kota. Apabila luas taman dan jumlah taman seimbang, maka tercipta kota yang asri dan berwawasan lingkungan.

Pertumbuhan penduduk di Jakarta Pusat saat ini mengalami peningkatan yang sangat pesat, sehingga kepadatan penduduk sudah tidak sebanding dengan lahan yang tersedia. Menurut data Suku Dinas Kependudukan dan Pencatatan Sipil Kota Administrasi penduduk Jakarta Pusat tahun 2010 berjumlah 923.301 jiwa dengan luas wilayah 4.790 hektar, sedangkan data dinas pertamanan DKI Jakarta luas Ruang Terbuka Hijau (RTH) sebesar 417,5 hektar $(8,7 \%)$. Kenyataan ini dapat menimbulkan ketidakserasian lingkungan hidup, karena areal tanah untuk ruang terbuka sangat sempit. Oleh sebab itu penyebaran Ruang Terbuka Hijau sangat penting untuk di tata agar lebih merata penyebarannya. Sehingga kehidupan masyarakat Jakarta Pusat akan lebih baik dan sehat.

Taman lingkungan merupakan bagian dari Ruang Terbuka Hijau yang dibangun didalam lingkungan permukiman, yang dibangun dan dikelola oleh pemerintah sebagai bagian dari ruang terbuka kota, biasanya termasuk di dalamnya taman bermain, fasilitas olah raga, dan lain-lain. Manfaat dari penyediaan taman lingkungan adalah menumbuhkan kesegaran, kenyamanan, keindahan lingkungan, menurunkan polusi, dan mewujudkan keserasian lingkungan.

Pemanfaatan taman lingkungan sangat tergantung pada pemeliharaan dan pengawasan penggunanya. Pemeliharaan taman lingkungan bukan hanya tanggung jawab pemerintah, tetapi diperlukan juga Peran serta warga sebagai pengguna fasilitas. Pemeliharaan diharapkan dilakukan oleh para penghuni atau masyarakat setempat. Melalui peran serta Sedangkan kegiatan pemeliharaan yang perlu diperhatikan, meliputi : penyiraman, pemangkasan, pembersihan, dan pemeliharaan hortikultural lain seperti penggantian tanaman yang rusak atau mati dan penananam kembali. Pada ruang terbatas, perlu perletakan wadah (pot) tanaman secara baik dan artistik, perlunya perbandingan proporsional antara tanaman pelindung dan tanaman perdu, semak dan penutup tanah dari unsur peteduh, hias, dan produktivitasnya. Pembangunan jalan setapak dan unit Taman Bermain, pelengkap pendukung bisa dengan sistem kerjasama antar lingkungan permukiman. 
Kelurahan Galur merupakan kelurahan yang terletak di Kecamatan Johar Baru, Jakarta Pusat. Kelurahan ini memiliki luas wilayah 26,2 Ha jumlah penduduk sebesar 18.219 jiwa terdiri dari 7 RW dan 84 RT. Kelurahan galur memiliki 5 taman lingkungan yang tersebar di 7 RW yaitu 1 taman lingkungan di RW 01, 2 taman lingkungan di RW 04 dan 2 taman lingkungan di RW 07 dengan luas keseluruhan $0,128 \mathrm{Ha}(0,48 \%)$. Di setiap RW ini memiliki kesadaran lingkungan terhadap pemeliharaan taman lingkungan berbeda-beda. Hal ini ditandai dengan kondisi taman lingkungan yang tidak merata. Yaitu taman lingkungan pada RT 012/RW 04 dengan luas $100 \mathrm{~m}^{2}$ memiliki lingkungan yang bersih dengan adanya tempat pembuangan sampah dan peraturan tentang larangan pembakaran sampah. Sedangkan taman lingkungan pada RT 003/07 dengan luas $531 \mathrm{~m}^{2}$ memiliki taman lingkungan yang kurang bersih seperti banyaknya timbunan sampah dan kurangnya pemeliharaan fasilitas bermain.

Dengan memperhatikan hal-hal yang telah dikemukakan di atas, maka sudah selayaknya bagi masyarakat kelurahan galur menyadari pentingnya taman lingkungan yang sudah terbangun dipelihara dan dirawat dengan baik. Upaya ini tentu saja memerlukan kesadaran dan peran serta masyarakat yang cukup tinggi, sehingga pemanfaatan taman lingkungan dapat dimanfaatkan secara maksimal. Khususnya mengenai kesadaran lingkungan masyarakat dalam pemeliharaan taman lingkungan pada RT 012/RW 04 dan RT 03/RW 07 Kelurahan Galur, Jakarta Pusat.

Kesadaran sebagai keadaan sadar, bukan merupakan keadaan yang pasif melainkan suatu proses aktif kesadaran adalah Tingkat kesiagaan individu pada saat ini terhadap rangsangan eksternal dan internal, artinya terhadap peristiwa-peristiwa lingkungan dan suasana tubuh, memori dan pikiran (Atkinson et. al 2000).

Berdasarkan definisi di atas kesadaran adalah kesadaran akan perbuatan (kepada keadaan yang sebenarnya), keadaan ingat akan dirinya, ingat kembali (dari pingsannya), siuman, bangun (dari tidur) ingat, tau dan mengerti. Kesadaran sangat berkaitan dengan manusia bahkan yang membedakan manusia dengan binatang. Kesadaran merupakan unsur dalam manusia dalam memahami realitas dan bagaimana cara bertindak atau menyikapi terhadap realitas. Manusia dengan dikaruniahi akal budi merupakan mahluk hidup yang sadar dengan dirinya. Kesadaran yang dimiliki oleh manusia kesadaran dalam diri, akan diri sesama, masa silam, dan kemungkinan masa depannya. Kesadaran sebagai keadaan sadar, bukan merupakan keadaan yang pasif melainkan suatu proses aktif. Memahami kesadaran perlu kiranya diaktualisasikan melalui sikap dan perilaku yang melibatkan langsung diri sendiri terhadap fenomena sosial yang terjadi di lingkungan masyarakat. 
Menurut Poerwadarminta (2002) dalam Kamus Umum Bahasa Indonesia istilah lingkungan berarti bulatan yang melingkung (melingkari) lingkaran atau sekalian yang terlingkung dalam suatu daerah "Penelaahan terhadap sikap dan perilaku manusia, dengan segenap tanggung jawab dan kewajiban maupun haknya untuk mencermati tata lingkungan dengan sebaik-baiknya”. (Soerjani et al. 2007)“Segala benda, kondisi, keadaan dan pengaruh yang terdapat dalam ruang yang kita tempati dan mempengaruhi hal-hal yang hidup, termasuk kehidupan manusia". (Salim 1981).

Berdasarkan teori di atas lingkungan merupakan bulatan yang melingkar dalam suatu daerah yang ditempati oleh segala kehidupan, termasuk kehidupan manusia. Termasuk dalam kontribusi menjaga dan memelihara lingkungan yang sehat dan nyaman.

Menurut Poerwadarminta (2002) dalam Kamus Umum Bahasa Indonesia kesadaran lingkungan ialah pengertian yang mendalam pada seseorang atau sekelompok orang yang terwujud dalam pemikiran, sikap dan tingkah laku yang mendukung pengembangan lingkungan.

Pendidikan lingkungan Hidup adalah suatu proses untuk membangun populasi manusia di dunia yang sadar dan peduli terhadap lingkungan total (keseluruhan) dan segala masalah yang berkaitan dengannya, dan masyarakat yang memiliki pengetahuan, ketrampilan, sikap dan tingkah laku, motivasi serta komitmen untuk bekerja sama, baik secara individu maupun secara kolektif, untuk dapat memecahkan berbagai masalah lingkungan saat ini, dan mencegah timbulnya masalah baru. Dalam Peraturan Menteri Dalam Negeri Nomor 1 Tahun 2007 Tentang Penataan Ruang Terbuka Hijau Kawasan Perkotaan Definisi Ruang Terbuka yaitu Ruang-ruang dalam kota atau wilayah yang lebih luas baik dalam bentuk area/kawasan maupun dalam bentuk area memanjang jalur di mana dalam penggunaannya lebih bersifat terbuka yang pada dasarnya tanpa bangunan.

Berdasarkan Peraturan Pemerintah Nomor 26 tahun 2008 tentang Rencana Tata Ruang Wilayah Nasional Definisi Ruang Terbuka Hijau (RTH) yaitu Ruang Terbuka Hijau adalah area memanjang/jalur dan/atau mengelompok, yang penggunaannya lebih bersifat terbuka, tempat tumbuh tanaman, baik yang tumbuh secara alamiah maupun yang sengaja ditanam.

Berdasarkan Penjelasan Pasal 29 Ayat (1) Undang-Undang Nomor 26 tahun 2007 tentang Penataan Ruang diketahui bahwa status kepemilikan Ruang Terbuka Hijau diklasifikasikan menjadi : 
1) Ruang Terbuka Hijau Publik, yaitu RTH yang berlokasi pada lahan-lahan publik atau lahan yang dimiliki oleh pemerintah pusat maupun daerah. Yang termasuk Ruang Terbuka Hijau Publik, antara lain, adalah taman kota, taman pemakaman umum, taman lingkungan dan jalur hijau.

2) Ruang Terbuka Hijau Privat adalah kebun atau halaman rumah/gedung milik masyarakat/swasta yang ditanami tumbuhan.

\section{Taman Lingkungan}

Berdasarkan Peraturan Menteri Pekerjaan Umum Nomor : 05/PRT/M/2008 tentang Pedoman Penyediaan dan Pemanfaatan Ruang Terbuka Hijau di kawasan perkotaan, Taman lingkungan adalah lahan terbuka yang berfungsi sosial dan estetik sebagai sarana kegiatan rekreatif, edukasi atau kegiatan lain pada tingkat lingkungan. Sedangkan berdasarkan Peraturan Menteri No. 1 Tahun 2007). Taman lingkungan (neighbourhood parks), merupakan ruang terbuka yang dibangun dalam lingkungan permukiman, dibangun dan dikelola oleh publik sebagai bagian dari zone ruang terbuka kota, atau sebagai bagian dari pembangunan perumahan privat baru, biasanya termasuk di dalamnya taman bermain, fasilitas olah raga, dan lain-lain.

Dari penjelasan tentang taman lingkungan dapat disimpulkan bahwa taman lingkungan merupakan bagian dari ruang terbuka publik yang dimiliki dan dikelola oleh pemerintah daerah kota yang digunakan untuk kepentingan masyarakat.

\section{Fungsi Taman Lingkungan}

1) Fungsi Ekologis, taman lingkungan dapat meningkatkan kualitas air tanah, mencegah banjir, mengurangi polusi udara dan pengatur iklim mikro.

2) Fungsi Sosial Budaya, keberadaan taman lingkungan dapat memberikan fungsi sebagai ruang interaksi sosial, sarana rekreasi dan sebagai tetenger (landmark) kota.

3) Fungsi Arsitektural, taman lingkungan dapat meningkatkan nilai keindahan dan kenyamanan lingkungan (Peraturan Menteri No. 1 Tahun 2007).

\section{Persyaratan dan Kriteria Standar Luasan Taman Lingkungan}

Persyaratan dan kriteria sarana taman lingkungan mempertimbangkan lokasi penempatan dan penyelesaian ruang untuk lebih jelasnya perhatikan tabel berikut : 
Tabel 1. Standar Luasan Taman Lingkungan

\begin{tabular}{|c|c|c|c|c|}
\hline No & $\begin{array}{c}\text { Unit } \\
\text { lingkungan }\end{array}$ & Tipe RTH & $\begin{array}{c}\text { Tipe minimal/ } \\
\text { Unit }\left(\mathbf{m}^{2}\right)\end{array}$ & Lokasi \\
\hline 1 & 250 jiwa & Taman RT & 250 & $\begin{array}{c}\text { di tengah } \\
\text { lingkungan RT }\end{array}$ \\
\hline 2 & 2500 jiwa & Taman RW & 1.250 & $\begin{array}{c}\text { di pusat kegiatan } \\
\text { RW }\end{array}$ \\
\hline 3 & 30.000 jiwa & Taman Kelurahan & 9.000 & $\begin{array}{c}\text { dikelompokan } \\
\text { dengan sekolah/ } \\
\text { pusat kelurahan }\end{array}$ \\
\hline 4 & $\begin{array}{c}120.000 \\
\text { jiwa }\end{array}$ & $\begin{array}{c}\text { Taman } \\
\text { kecamatan }\end{array}$ & 24.000 & $\begin{array}{c}\text { dikelompokan } \\
\text { dengan sekolah/ } \\
\text { pusat kecamatan }\end{array}$ \\
\hline
\end{tabular}

Sumber : Peraturan Menteri Pekerjaan Umum Nomor : 05/PRT/M/2008

Mencermati fenomena lingkungan yang terjadi, khususnya yang berkaitan dengan pemeliharaan taman lingkungan di Jakarta Pusat. Perlunya penelitian ini dalam rangka mengetahui tingkat Kesadaran Lingkungan Masyarakat yang nantinya menjadi sebuah peluang peningkatan kualitas pemeliharaan taman lingkungan di Jakarta pusat dengan menggali preferensi masyarakat serta kebijakan Stakeholder.

\section{METODA}

Dalam penelitian ini metode yang digunakan adalah metode deskriptif dengan menggunakan instrumen kuesioner yang bersifat survei. Penelitian ini yang menjadi objek yaitu kesadaran lingkungan masyarakat kelurahan galur. Populasi dalam penelitian ini adalah warga kelurahan galur RT 012/RW 04 dan RT 03/RW 07, Kecamatan Johar Baru, Jakarta Pusat.

Tabel 2. Jumlah Penduduk Kelurahan Galur desember 2010

\begin{tabular}{|c|c|c|c|}
\hline No. & RW & KK & Jumlah Jiwa \\
\hline 1 & 01 & 471 & 2.099 \\
2 & 02 & 462 & 2.143 \\
3 & 03 & 493 & 2.184 \\
4 & 04 & 525 & 3.580 \\
5 & 05 & 421 & 2.958 \\
6 & 06 & 407 & 2.869 \\
7 & 07 & 499 & 2.385 \\
\hline Jumlah & $\mathbf{7}$ & $\mathbf{3 2 7 8}$ & $\mathbf{1 8 . 2 1 9}$ \\
\hline
\end{tabular}

Sumber: Arsip Kelurahan Galur (2010)

Sampel penelitian ini ditentukan dengan menggunakan Purposive Sample (sampel bertujuan). Sampel yang digunakan dalam penelitian ini adalah warga Kelurahan Galur RT 012/RW 04 dan RT 03/RW 07, Kecamatan galur, Jakarta Pusat. Pengambilan sampel berdasarkan rumus dari 
Taro Yamane dengan catatan bahwa populasi sudah diketahui dengan perhitungan sebagai berikut (Riduwan, 2005:249):

$$
\begin{aligned}
\text { Dimana }: \mathrm{n} & =\text { Jumlah sampel } \\
\mathrm{N} & =\text { Jumlah populasi } \\
\mathrm{d}^{2} & =\text { Presisi yang ditetapkan }
\end{aligned}
$$

Jumlah populasi (N) pada RT 012/RW 04 sebesar 525 KK dan RT 03/RW 07. Sebesar 499 Tingkat presisi $(\mathrm{d})$ yang ditetapkan sebesar $=20 \%$. Berdasarkan rumus diatas, jumlah sampel (n) dapat dihitung sebagai berikut :

$$
\mathrm{n}=\frac{N}{N \cdot d^{2}+1}
$$

Jumlah sampel pada RT 012/RW 04 dengan jumlah 525

$$
n=\frac{N}{N \cdot d^{2}+1}=\frac{525}{(525) \cdot(0,2)^{2}+1}=\frac{525}{22}=23,86 \approx 25 \text { responden }
$$

Jumlah sampel pada RT 03/RW 07 dengan jumlah 499

$$
n=\frac{N}{N \cdot d^{2}+1}=\frac{499}{(499) \cdot(0,2)^{2}+1}=\frac{499}{20,96}=23,86 \approx 25 \text { responden }
$$

Tabel 3. Jumlah sampel RT 012/RW 04 dan RT 03/RW 07 Kelurahan Galur.

\begin{tabular}{|c|c|c|c|}
\hline No & Warga Kelurahan Galur & Jumlah populasi & Jumlah sampel \\
\hline 1. & Warga RW 04 & $525 \mathrm{KK}$ & $25 \mathrm{KK}$ \\
\hline 2. & Warga RW 07 & $499 \mathrm{KK}$ & $25 \mathrm{KK}$ \\
\hline \multicolumn{2}{|c|}{ Jumlah Keseluruhan } & $1024 \mathrm{KK}$ & $50 \mathrm{KK}$ \\
\hline
\end{tabular}

Sumber : Kelurahan Galur (2010)

Data yang dibutuhkan dalam penelitian ini diperoleh melalui instrumen, instrumennya adalah kuesioner. Instrumen yang baik dan benar akan mampu menghimpun data secara obyektif, lengkap, dan dapat diolah untuk memecahkan masalah penelitian. Instrumen dibuat sesuai dengan kisi-kisi, kemudian dari kisi-kisi diperoleh 20 butir kuesioner. 
Instrumen pada penelitian ini terdiri dari indikator-indikator dari kesadaran lingkungan masyarakat kelurahan galur yaitu pengetahuan, sikap/perilaku dan gaya hidup. Kemudian dari indikator tersebut diberikan sub indikator seperti yang tertera pada tabel 3.3.

Tabel 4. Kisi-Kisi Instrumen Uji Coba

\begin{tabular}{|c|c|c|}
\hline Variabel & Indikator & Sub Indikator \\
\hline \multirow{3}{*}{$\begin{array}{l}\text { Kesadaran } \\
\text { lingkungan } \\
\text { masyarakat dalam } \\
\text { memelihara taman } \\
\text { lingkungan di } \\
\text { kelurahan galur }\end{array}$} & 1.Pengetahuan & $\begin{array}{l}\text { 1. Pengertian taman lingkungan. } \\
\text { 2. Fungsi taman lingkungan. }\end{array}$ \\
\hline & 2.Sikap/Perilaku & $\begin{array}{ll}\text { 1. } & \text { Kondisi taman lingkungan. } \\
\text { 2. } & \text { Sarana dan prasarana } \\
\text { 3. } & \text { Peran serta masyarakat } \\
\text { 4. } & \text { memelihara taman } \\
\text { 5. } & \text { Alih fungsi } \\
\text { 3. } & \text { Sosialisasi dan penyuluhan }\end{array}$ \\
\hline & 3. Gaya hidup & $\begin{array}{ll}\text { 1. } & \text { Aktivitas Masyarakat } \\
\text { 2. } & \text { Minat Masyarakat }\end{array}$ \\
\hline
\end{tabular}

Teknik analisis data yang digunakan adalah analisis deskriptif. Teknik analisis data yang dimaksud dalam penelitian ini adalah analisis terhadap data, yang diperoleh dari kuesioner atau kuesioner. Setelah dianalisis kemudian ditarik kesimpulan sehingga akan diperoleh suatu kebenaran dalam hasil penelitian. 


\section{HASIL DAN PEMBAHASAN}

Berdasarkan Data Dinas Pertamanan dan Pemakaman DKI Jakarta terdapat 5 (lima) kecamatan yang memilki taman lingkungan dengan rincian 6 taman lingkungan pada Kecamatan Kemayoran, 10 taman lingkungan pada Kecamatan Johar Baru, 1 taman lingkungan pada Kecamatan Cempaka Putih Barat, 3 taman lingkungan pada Kecamatan Senen dan 2 taman lingkungan pada Kecamatan Tanah Abang. Untuk lebih jelasnya dapat dilihat pada lampiran 6 Data Taman lingkungan Jakarta Pusat, Halaman 50.

Dengan banyaknya penyebaran taman lingkungan yang ada di Jakarta Pusat, maka dipilih 2 taman lingkungan yang berada di kecamatan Johar Baru, kelurahan Galur yaitu : Taman Kewista 19 dengan luas $\pm 100 \mathrm{~m}^{2}(10 \mathrm{~m} \times 10 \mathrm{~m})$ dan Taman Rawa Tengah IVA dengan luas \pm $351 \mathrm{~m}^{2}(13 \mathrm{~m} \times 27 \mathrm{~m})$.

\section{Kondisi taman lingkungan pada RT 012/04 dan RT 03/07}

Kondisi taman lingkungan pada RT 012/04 ini dapat dilihat keadaannya bersih dan terpelihara dengan baik. Disepanjang areal taman tidak terdapat sampah yang bertumpuk dan berserakan sembarangan. dan ada tempat sampah yang disediakan oleh masyarakat untuk membuang sampah. Kemudian terdapat sebuah spanduk yang isinya tentang peraturan untuk tidak membakar sampah di areal taman. untuk meminimalisasi penumpukan sampah terdapat pembuatan kompos yang diprakarsai oleh RT/RW, sehingga keberadaan sampah organik sangat penting dan dapat dimanfaatkan dengan baik. Di areal yang luasnya hanya $\pm 100 \mathrm{~m}^{2}$ masih terdapat vegetasi berupa rerumputan, perdu, tanaman hias dan pohon peneduh yang mendukung penghijauan dan keasrian taman. Dan memang hanya dari segi fasilitas saja yang masih kurang lengkap yaitu berupa ornamen pendukung seperti lampu taman, jam dan kolam taman. Kemudian dari fasilitas yang tersedia, perlu dilakukan pengecatan ulang karena adanya pengelupasan pada fasilitas yang ada. Melihat kondisi taman lingkungan di RT 012/04 ini. Diperlukan peran serta masyarakat sebagai pengguna Dan Sudin Pertamanan Jakarta Pusat sebagai pengelola taman lingkungan dalam rangka pemeliharaan yang lebih baik.

Lain halnya dengan taman linkungan di RT 012/04. kondisi taman lingkungan di RT 03/07 sangat memprihatinkan. Di areal yang luasnya $\pm 351 \mathrm{~m}^{2}$ masih terdapat sampah yang berserakan dan menumpuk dibeberapa tempat, karena memang ketidaktersediaan tempat pembuangan sampah. Disamping itu, tidak adanya pembatas antara rumah warga dengan taman lingkungan. Sehingga sebagian ada yang memungkinkan warga membuang sampah di taman. Kemudian vegetasi berupa rerumputan, perdu, tanaman hias dan pohon peneduh terlihat kering 
dan gersang, sebaiknya ada pepohonan yang rindang dan terpelihara, sehingga membuat taman lebih nyaman dan sejuk. Sedangkan dari fasilitas yang tersedia, perlu dilakukan perbaikan. Melihat kondisi taman lingkungan di RT 03/07 ini. Dibutuhkan keseriusan dari Sudin Pertamanan Jakarta sebagai pengelola dan khususnya peran serta masyarakat sebagai pengguna taman lingkungan dalam rangka menjaga kualitas lingkungan, sehingga pemanfaatan taman lingkungan dapat dirasakan secara maksimal.

\section{Pendapat Warga}

Berdasarkan data yang diperoleh dari kuesioner, kemudian data pernyataan warga diolah dengan skor interpretasi penilaian (\%) sebagai berikut :

Tabel 5. Data Pernyataan Keseluruhan Responden pada indikator pengetahuan

\begin{tabular}{|c|l|c|c|}
\hline \multirow{2}{*}{ No } & \multicolumn{1}{|c|}{ Pernyataan } & RT 12/04 & RT 03/07 \\
\cline { 3 - 4 } & \multicolumn{2}{|c|}{ Persentase Pemilih (\%) } \\
\hline 1 & $\begin{array}{l}\text { Taman lingkungan adalah ruang terbuka } \\
\text { publik yang dibangunan untuk kepentingan } \\
\text { umum. }\end{array}$ & 94,67 & 70,67 \\
\hline 2 & $\begin{array}{l}\text { Fungsi taman lingkungan adalah untuk } \\
\text { interaksi sosial warga sekitar. }\end{array}$ & 82,67 & 90,67 \\
\hline
\end{tabular}

Tabel 6. Data Pernyataan Keseluruhan Responden pada indikator Sikap/perilaku

\begin{tabular}{|c|l|c|c|}
\hline \multirow{2}{*}{ No } & \multicolumn{1}{|c|}{ Pernyataan } & RT 12/04 & RT 03/07 \\
\cline { 3 - 4 } & \multicolumn{1}{|c|}{$\begin{array}{c}\text { Kersentase Pemilih (\%) } \\
\text { baik. }\end{array}$} & 85,33 & 53,33 \\
\hline 2 & Fasilitas yang ada di taman lingkungan memprihatinkan. & 65,33 & 45,33 \\
\hline 3 & Suka melakukan kerja bakti di taman lingkungan. & 84,00 & 88,00 \\
\hline 4 & $\begin{array}{l}\text { Pembersihan area taman lingkungan dalam rangka } \\
\text { pemeliharaan. }\end{array}$ & 50,67 & 89,33 \\
\hline 5 & Pemanfaatan taman lingkungan kurang diminati. & 58,67 & 66,67 \\
\hline 6 & Taman lingkungan merupakan tempat untuk berjualan. & 70,67 & 54,67 \\
\hline 7 & $\begin{array}{l}\text { Penyuluhan dari Sudin Pertamanan DKI Jakarta sangat } \\
\text { diperlukan bagi warga. }\end{array}$ & 62,67 & 88,00 \\
\hline 8 & Taman lingkungan harus dipelihara secara rutin dan terjadwal. & 85,33 & 92,00 \\
\hline 9 & Sosialisasi taman lingkungan sangat dibutuhkan bagi warga. & 94,67 & 93,33 \\
\hline 10 & taman lingkungan lebih baik berubah fungsi menjadi bangunan. & 86,67 & 58,67 \\
\hline
\end{tabular}


Tabel 7. Data Pernyataan Keseluruhan Responden pada indikator Gaya Hidup

\begin{tabular}{|c|l|c|c|}
\hline \multirow{2}{*}{ No } & \multicolumn{1}{|c|}{ Pernyataan } & RT 12/04 & RT 03/07 \\
\cline { 3 - 4 } & \multicolumn{2}{|c|}{ Persentase Pemilih (\%) } \\
\hline 1 & $\begin{array}{l}\text { Suka mengajak keluarga bermain di } \\
\text { taman lingkungan. }\end{array}$ & 80,00 & 48,00 \\
\hline 2 & Suka berteduh di taman lingkungan. & 81,33 & 45,33 \\
\hline 3 & $\begin{array}{l}\text { Banyak sampah menumpuk dan } \\
\text { berserakan di taman lingkungan. }\end{array}$ & 86,67 & 49,33 \\
\hline \multirow{2}{*}{4} & $\begin{array}{l}\text { Tidak Terjadinya kenyamanan dan } \\
\text { keindahan lingkungan akibat } \\
\text { membuang sampah sembarang di } \\
\text { taman lingkungan. }\end{array}$ & 81,33 & 77,33 \\
\hline
\end{tabular}

\section{Hasil Penelitian}

Berdasarkan pengolahan data kuesioner warga, maka hasil penelitian diperoleh sebagai berikut :

Tabel 8. Data hasil rata-rata Kesadaran lingkungan Kelurahan Galur.

\begin{tabular}{|l|c|c|}
\hline \multicolumn{1}{|c|}{ Indikator } & RT 12/04 (\%) & RT 03/07 (\%) \\
\hline Pengetahun & & \\
1. Pengertian taman lingkungan. & 94,67 & 70,67 \\
2. Fungsi taman lingkungan. & 82,67 & 90,67 \\
\hline Rata-rata indikator pengetahuan & $\mathbf{8 8 , 6 7}$ & $\mathbf{8 0 , 6 7}$ \\
\hline Sikap/tingkah laku & & \\
1. Kondisi taman lingkungan. & 85,33 & 53,33 \\
2. Sarana dan prasarana & 65,33 & 45,33 \\
3. Peran serta masyarakat & 71,33 & 77,33 \\
4. Pemeliharaan taman & 68 & 90,66 \\
5. Alih fungsi & 78,67 & 63,33 \\
6. Sosialisasi dan penyuluhan & 78,67 & 80 \\
\hline Rata-rata indikator Sikap/perilaku & $\mathbf{7 4 , 5 5}$ & $\mathbf{6 8 , 3 3}$ \\
\hline Gaya Hidup & & \\
1. Aktivitas Masyarakat & 80,66 & 46,66 \\
2. Minat Masyarakat & 84 & 63,33 \\
\hline Rata-rata indikator gaya hidup & $\mathbf{8 2 , 3 3}$ & $\mathbf{5 5}$ \\
\hline
\end{tabular}

Hasil penelitian kesadaran lingkungan masyarakat dalam pemeliharaan taman lingkungan di Jakarta Pusat dikonsultasikan dengan skor interpretasi penilaian pembanding dari standar penilaian skor. dengan menggunakan PAP Penjenjangan nilai yang disesuaikan dengan kategori berikut : 
Tabel 9. Skor Interpretasi Penilaian

\begin{tabular}{|c|c|}
\hline Rata-rata Skor (\%) & Klasifikasi \\
\hline $80-100$ & Sangat Baik \\
\hline $70-79$ & Baik \\
\hline $60-69$ & Cukup \\
\hline $55-59$ & Kurang \\
\hline$<55$ & Sangat Kurang \\
\hline
\end{tabular}

Berdasarkan Data hasil rata-rata Kesadaran lingkungan dan Skor Interpretasi Penilaian, maka Hasil Interpretasi diperoleh sebagai berikut :

Tabel 10. Hasil Interpretasi Kesadaran Lingkungan Kelurahan Galur

\begin{tabular}{|l|c|c|c|c|}
\hline \multicolumn{1}{|c|}{ Indikator } & RT 12/04 (\%) & Klasifikasi & RT 03/07 (\%) & Klasifikasi \\
\hline Pengetahuan & 88,67 & Sangat Baik & 80,67 & Sangat Baik \\
\hline Sikap/Perilaku & 74,55 & Baik & 68,33 & Cukup \\
\hline Gaya hidup & 82,33 & Sangat Baik & 55 & Kurang \\
\hline
\end{tabular}

Berdasarkan hasil penelitian dapat dilihat bahwa kesadaran lingkungan masyarakat dalam pemeliharaan taman lingkungan pada RT 12/04 untuk nilai keseluruhan pada indikator pengetahuan adalah 88,67 \% yang menunjukkan bahwa pengetahuan masyarakat tentang taman lingkungan adalah sangat baik. Untuk indikator sikap/perilaku dalam pemeliharaan taman lingkungan adalah $74,55 \%$ yang menunjukkan bahwa sikap/perilaku masyarakat untuk memelihara taman lingkungan adalah baik. Sedang nilai indikator gaya hidup adalah $82,33 \%$ yang menunjukan bahwa indikator gaya hidup adalah sangat baik.

Lain halnya kesadaran lingkungan masyarakat dalam pemeliharaan taman lingkungan pada RT 03/07 untuk nilai keseluruhan pada indikator pengetahuan adalah 80,67 \% yang menunjukkan bahwa pengetahuan masyarakat tentang taman lingkungan adalah sangat baik Untuk indikator sikap/perilaku dalam pemeliharaan taman lingkungan adalah 68,33 \% yang menunjukkan bahwa sikap/perilaku masyarakat untuk memelihara taman lingkungan adalah cukup. Sedangkan nilai indikator gaya hidup adalah $55 \%$ yang menunjukan bahwa indikator gaya hidup adalah Kurang.

\section{KESIMPULAN}

1) Pada RT 012/04, menunjukkan tingkat pengetahuan yang baik dengan persentase $88,67 \%$ atau kesadaran lingkungan sangat baik Pada sikap/perilaku dengan persentase $74,55 \%$ ini menunjukkan kesadaran lingkungan baik, sedangkan pada gaya hidup menunjukkan persentase $82,33 \%$ yang berarti kesadaran lingkungan sangat baik. Secara keseluruhan 
RT 012/04 sesuai dengan kondisi taman lingkungan yang baik dan bersih. Hasil survey terhadap 3 indikator dapat dikatakan baik.

2) Pada RT 03/07, menunjukkan tingkat pengetahuan yang baik dengan persentase $80,67 \%$ atau kesadaran lingkungan baik. Pada sikap/perilaku dengan persentase 68,33\% ini menunjukkan kesadaran lingkungan cukup, sedangkan pada gaya hidup menunjukkan persentase 55 \% yang berarti kesadaran lingkungan kurang. Secara keseluruhan RT 03/07 pada indikator pengetahuan memiliki kesadaran lingkungan baik, namun untuk indikator sikap/perilaku dan gaya hidup dapat dikatakan kurang. Dan kondisi taman lingkungan memang kurang baik dan besih.

3) Berdasarkan hasil survei lapangan dengan warga di wilayah RT 012/04 dan RT 03/07 dapat disimpulkan bahwa pemeliharaan taman lingkungan kurang disosialisasikan oleh RT/RW kepada warganya. Sehingga pemeliharaan taman lingkungan hanya sebatas kesadaran dari masing-masing warga. Warga membutuhkan penyuluhan dari suku dinas pertamanan Jakarta Pusat untuk lebih mengetahui dan memahami dalam memelihara taman lingkungan.

\section{DAFTAR PUSTAKA}

Anonim. 2010. Perilaku Manusia. [Terhubung berkala]. Hhtp://wapedia.mobi/id/perlaku_manusia. Html [12 Agustus].

Arikunto S. 2002. Prosedur Penelitian: Suatu Pendekatan Praktek. Jakarta : Rineka Cipta.

Atkinson, 1987. Pengantar Psikologi jilid I dan II. Jakarta: Penerbit Erlangga.

Departemen Pendidikan Nasional. 1994. Kamus Besar Bahasa Indonesia. Ed ke-6. Jakarta: Balai Pustaka.

Departemen Pendidikan Nasional. 2002. Kamus Umum Bahasa Indonesia. Ed ke-4. Jakarta: Balai Pustaka.

Dinas Tata Kota. 2005. Rencana Rinci Tata Ruang Wilayah Jakarta Pusat. Jakarta: Dinas Tata Kota - PEMPROV DKI Jakarta.

Dirdjosisworo, Soejono. 1991. Sosiologi dan Filsafat. Jakarta : Erlangga.

Echols dan Shadily. 1976. Kamus Inggris Indonesia. Jakarta: Gramedia.

Fakultas Teknik. 2009. Buku Pedoman Skripsi / Komprehensif / Karya Inovatif (S1). Jakarta: Fakultas Teknik, Universitas Negeri Jakarta.

Arifin, Hadi S. 1996. Pemeliharaan Taman. Jakarta : Penebar Swadaya 
Hirnawan F. 1998. Manusia, Kesehatan dan Lingkungan: Kualitas Hidup dalam Perspektif Perubahan Lingkungan Global. Bandung: Penerbit Alumni.

Koentjaraningrat. 2005. Pengantar Antropologi. Jakarta: Rineka Cipta.

Kotler, Philip 2002. Manajemen Pemasaran.(Edisi Milenium). (Benyamin Molan, Trans), Jakarta :

PT Prenhallindo

Neolaka, Amos. 2008. Kesadaran Lingkungan. Jakarta: Rineka Cipta.

Poerwadarminta, WJS. 2002. Kamus Umum Bahasa Indonesia. Jakarta: Balai Pustaka.

Purnohadi, Ning. 2006. Ruang Terbuka Hijau Sebagai Unsur Utama Tata Ruang Kota. Jakarta :

Dirjen Penata Ruang Departemen Pekerja Umum.

Republik Indonesia. Peraturan Pemerintah No.69 tahun 1996 tentang Pelaksanaan Hak dan Kewajiban, Serta Bentuk dan Tata Cara Peran Serta Masyarakat.

Republik Indonesia. Peraturan Pemerintah Nomor 26 Tahun 2008 Tentang Rencana Tata Ruang Wilayah Nasional

Republik Indonesia. Peraturan Menteri Dalam Negeri Nomor 1 Tahun 2007 Tentang Penataan

Ruang Terbuka Hijau Kawasan Perkotaan.

Republik Indonesia. Peraturan Menteri Pekerjaan Umum Nomor : 5/PRT/M/2008 Tentang

Pedoman Penyediaan dan Pemanfaatan Ruang Terbuka Hijau di Kawasan Perkotaan.

Riduwan. 2007. Rumus dan Data dalam Aplikasi Statistika (Cet.ke-2). Bandung: Alfabeta

Salim, Emil. 1983. Lingkungan Hidup dan Pembangunan. Jakarta: Mutiara.

Soemarwoto, Otto. 2001. Atur-Diri-sendiri: Paradigma Baru dalam Pengelolaan Lingkungan

Hidup. Yogyakarta: Gadjah Mada University Press.

Soerjani, Mohamad. 2007. Lingkungan Hidup : Pendidikan Pengelolaan Lingkungan dan

Kelangsungan Pembangunan. Jakarta : Yayasan IPPL. 